\title{
Maksuvalmiuslaskelmat ja tunnusluvut
}

\author{
Olli Rantala
}

MTT Taloustutkimus, Luutnantintie 13,00410 Helsinki,olli.rantala@mtt.fi

Maa- ja puutarhataloudessa toiminnan rahoituksen ja maksuvalmiuden merkitys on kannattavuuden ohella taloudellisten toimintaedellytysten tarkastelussa tärkeää. Yrityksen on selviydyttävä sekä lyhyellä että pitkällä aikavälillä maksuvelvoitteistaan, jotta toiminta voisi häiriöttä jatkua. Maksuvalmius tarkoittaa tulorahoituksen riittävyyttä ja sen tarkastelussa käytetään perinteisen taseanalyysin tunnuslukuja ja erilaisia rahavirtalaskelmia.

Maatilayritysten kannattavuuskirjanpidossa maksuvalmiuden tarkastelu perustuu kassavirtalaskelmiin (www.mtt.fi/taloustohtori). Laskelman rakenne on Ytn:n suosituksen mukainen, jossa tarkastellaan tulorahojen riittävyyttä rahankäytön eri kohteisiin niiden taloudellisessa etuoikeusjärjestyksessä. Rahoituksen riittävyyttä mitataan eri tasoille lasketuilla toiminta-, rahoitus-, investointi- ja kassajäämillä. Kassavirtojen kuvauksen avulla voidaan tutkia paitsi rahoituksen riittävyyttä, pääomarahoituksen tarvetta, lainojen hoito- ja verorasitetta, erilaisten maksujen ja velvoitteiden hoitokykyä ja yleensäkin rahoituksen hallintaa ja tehokkuutta.

Vuonna 2008 maa- ja puutarhatalouden kassatulot olivat keskimäärin 130700 euroa, josta lyhytvaikutteisiin toiminnan menoihin kului 83700 eli $64 \%$, joten toimintajäämäksi jäi 47000 euroa. Rahoitusmenojen ja verojen vähentämisen jälkeen rahoitusjäämäksi jäi 36700 euroa. Kun siitä vähennetään siitä nettomääräiset investointimenot, saadaan investointijäämäksi 7200 euroa. Nettomääräiset investointimenot olivat 29500 euroa. Kassajäämään päästään lisäämällä investointiavustukset ja lainojen nettomuutos. Kassan ylijäämäksi muodostui 17800 euroa, joka kattaa rahoitusomaisuuden muutoksen ja jäi käytettäväksi yksityiseen kulutukseen.

Kassamenojen kasvu on viime vuosina ollut hieman tulojen kasvua nopeampaa, mutta tulorahoitus ei ole kuitenkaan merkittävästi heikentynyt. Tulorahoituksella on pystytty maksamaan toiminnan menot, rahoitusmenot ja verot ja myös investointeihin on jäänyt rahaa. Positiivinen investointijäämä osoittaa, että investoinnit on keskimäärin voitu rahoittaa tulorahoituksella. Isompia investointeja sillä ei kuitenkaan pystytä rahoittamaan, vaan rahoitukseen käytetään avustuksia ja velkaa. Investointitukien määrä oli vuosina 2007 - 2008 keskimäärin 2900 euroa ja lainojen nettolisäys 8400 euroa tilaa kohti.

Kassaperusteisen tulorahoituksen riittävyyttä voidaan arvioida suhteessa vieraan pääoman hoitomenoihin tai suhteessa investointeihin. Lainojen hoitokate mittaa tulorahoituksen riittävyyttä vieraasta pääomasta aiheutuviin maksuihin ja vieraan pääoman takaisinmaksuaika puolestaan mittaa velkojen takaisinmaksukykyä. Molemmat tunnusluvut voidaan laskea eri olettamuksilla yrittäjän voitonjako-osuudesta tulorahavirrasta. Kun yrittäjän osuutena tulorahoituksesta käytetään työlle saatua korvausta eli työn tuottoa, on lainojen hoitokate 2000-luvulla ollut keskimäärin 1,2 ja vieraan pääoman takaisinmaksuaika 4,8 vuotta. Käytetyillä laskentaperusteilla maksuvalmiutta voidaan pitää yleisten ohjelukujen mukaan tyydyttävänä eli liiketoiminnan kassavirta riittää lainojen hoitokuluihin ja takaisinmaksuajat ovat kohtuullisia.

Lainojen hoitokatteella mitattu velkojen hoitokyky oli vuonna 2008 heikoin muilla kotieläintiloilla ja sikatiloilla ja paras lypsykarjatiloilla. Muilla nautakarjatiloilla suuri velkaisuus ja puutarhayrityksissä puolestaan pieni rahoitusjäämä pidensivät selvästi takaisinmaksuaikoja. Tunnuslukujen valossa viljatilojen maksuvalmius pysyi kohtuullisena vuonna 2008 vaikka kannattavuus ja yrittäjätulo putosivat rajusti edellisvuodesta. Viljatilojen velkaisuus on myös pysynyt viime vuodet varsin kohtuullisena. Sikatilojen maksuvalmius heikkeni selvästi vuonna 2008 kannattavuuden pudotessa. Lypsykarjatilojen maksuvalmius on pysynyt vähintäänkin tyydyttävänä. Rahoitusjäämä on kasvanut 2000-luvulla rahatulojen vauhdissa ja velkaisuus on pysynyt kohtuullisena.

Asiasanat: Kannattavuuskirjanpito, kannattavuus, maksuvalmius, tunnusluvut 


\section{Johdanto}

Yritystoiminnan kannattavuus ja rahoitus ovat keskeiset osa-alueet taloudellisten toimintaedellytysten arvioinnissa. Maatilayritysten kannattavuuskirjanpidossa kannattavuutta mitataan suoriteperusteella laadittujen tilinpäätösten perusteella. Tilikauden tulot ja menot kohdistetaan suoriteperusteen mukaisesti tuotoiksi ja kustannuksiksi sille tilikaudelle, jolloin tuotanto on saatu aikaan. Näin saadaan tilinpäätökseen oikeat tiedot kunkin tilikauden yritystoiminnan taloudellisen tilanteen ja kehityksen arviointia varten. Tässä arvioinnissa käytetään useita liiketoiminnan tulosta ja vakavaraisuutta mittaavia tunnuslukuja.

Maa- ja puutarhataloudessa rahoituksen merkitys on kannattavuuden ohella taloudellisten toimintaedellytysten tarkastelussa tärkeää. Yrityksen on selviydyttävä sekä lyhyellä että pitkällä aikavälillä maksuvelvoitteistaan, jotta toiminta voisi häiriöttä jatkua. Kasvuun liittyvä investointihyödykkeisiin ja vaihto-omaisuuteen sitoutuvan pääomapanoksen kasvu ja pääoman suhteellisen hidas kierto kasvaneiden hinta- ja markkinariskien olosuhteissa korostavat rahoituksen tärkeyttä ja sen hallintaa. Rahoituksen arviointiin liittyy läheisesti tarkastelun aikaväli. Pitkällä aikavälillä kyse on pääomarakenteesta eli oman ja vieraan pääoman suhteesta ja velkojen määrästä suhteessa liiketoiminnan laajuuteen. Vieraalla pääomalla laajennetaan rahoituksellisia resursseja suuremmiksi kuin mitä ne olisivat pelkästään oman pääoman varassa. Vieras pääoma on toisaalta joustamatonta ja aiheuttaa maksuvelvoitteita yritykselle.

\section{Kassavirtalaskelma maksuvalmiuden mittaamisessa}

Rahoituksen lyhyen aikavälin mittari on maksuvalmius. Sen tarkastelussa käytetään perinteisen taseanalyysin tunnuslukuja ja erilaisia rahavirtalaskelmia. Kannattavuuskirjanpidossa maksuvalmiuden tarkastelu perustuu maa- ja puutarhatalouden maksuperusteisiin rahavirtalaskelmiin (www.mtt.fi/taloustohtori). Laskelmien rakenne on Yritystutkimusneuvottelukunnan esittämän mallin mukainen ns. puhdas kassavirtalaskelma. Kassavirta-analyysi osoittaa, mistä rahoitusvarat tulevat, minne ne on käytetty ja miten liiketoiminnan aikaansaama tulorahavirta on riittänyt rahankäytön eri tarpeisiin niiden taloudellisessa etuoikeusjärjestyksessä. Yrityksen toimintojen aikaansaamat rahavirrat jaetaan varsinaisen liiketoiminnan, investointien ja rahoituksen rahavirtoihin. Saadut ja maksetut maksut esitetään luonteensa mukaisissa rahavirroissa.

Rahoituksen riittävyyttä mitataan eri tasoille lasketuilla jäämillä, jotka osoittavat, paljonko rahaa on käytettävissä jäljellä oleviin rahan käytön tarpeisiin ja miten mahdollinen alijäämä on katettu. Kassavirtojen kuvauksen avulla voidaan tutkia paitsi rahoituksen riittävyyttä, pääomarahoituksen tarvetta, erilaisten maksujen ja velvoitteiden hoitokykyä, erityisesti velkojen hoitokykyä, korko- ja verorasitetta ja yleensäkin rahoituksen hallintaa ja tehokkuutta.

\section{Liiketoiminnan kassajäämä}

Maa- ja puutarhatalouden liiketoiminnan kassatulot olivat vuonna 2008 keskimäärin 130700 euroa, josta tukien osuus oli $36 \%$. Tuloslaskelman kokonaistuotot olivat vastaavasti 127600 euroa, ero kassatuloihin johtuu varastojen pienentymisestä. Rahatuloista kului lyhytvaikutteisiin toiminnan menoihin 83700 eli $64 \%$, joten toimintajäämäksi jäi 47000 euroa eli $36 \%$ rahatuloista. Toimintajäämä osoittaa, paljonko tuloista on jäljellä juoksevien toimintamenojen jälkeen käytettäväksi vieraan pääoman kuluihin ja veroihin, investointien omarahoitukseen, lainojen lyhennyksiin ja yksityismenoihin.

\section{Kassaperusteinen tulorahoitus}

Rahoitusjäämä saadaan, kun toimintajäämästä vähennetään ulos maksettavina voitonjakoerinä rahoitusmenot ja verot. Rahoitusjäämäksi jäi vuonna 2008 keskimäärin 36700 euroa eli $28 \%$ tuloista. Koska toimintamenoja eikä voitonjakoeriä ainakaan useamman vuoden aikavälillä ole järkevää rahoittaa vieraalla pääomalla, tarjoaa rahoitusjäämä hyvän kriteerin maksuvalmiuden tulorahoitusnäkökulmalle. Rahoitusjäämän tulisi olla positiivinen, jotta tulorahoitus olisi riittävä. Jos 
rahoitusjäämä on negatiivinen, toimintaa on rahoitettava aikaisemmin kertyneillä rahavaroilla, ottamalla velkaa, myymällä omaisuutta tai omistajan sijoituksina esim. metsä- tai palkkatuloilla. Laskelmassa ei ole vähennetty yrittäjän palkkaa menona eikä yksityisottoa ole vähennetty voitonjakoeränä, joten rahoitusjäämä kattaa myös yrittäjän osuuden tulorahavirrasta. Maatalouden harjoittaja ei saa ennalta määrättyä osaa tuloista voitonjakona vaan jäännöserän, jos toiminta tuottaa ylijäämää.

\section{Investointien kassavirta}

Rahoitusjäämä on käytettävissä mm. investointeihin ja lainojen lyhennyksiin. Investoinnit ovat muusta rahankäytöstä erillinen päätös, johon tulorahoitus vain osittain vaikuttaa. Pitkävaikutteisissa menoissa on enemmän ajallista joustovaraa ja ainakin suuremmat investoinnit maksetaan pääomarahoituksella, omalla tai vieraalla. Pitkällä aikavälillä kuitenkin myös investointimenot on voitava kattaa tuloilla. Investointien rahavirta käsittää investointimenot ja omaisuuden myyntitulot. Investointimenot olivat vuonna 2008 keskimäärin 34700 euroa ja omaisuuden myyntitulot 5200 euroa tilaa kohti. Kun rahoitusjäämästä vähennetään nettomääräiset investointimenot, jäi investointijäämäksi 7200 euroa.

\section{Rahoituksen kassavirta}

Rahoituksen kassavirta käsittää lainojen nostot ja lyhennykset sekä investointiavustukset. Lainoja nostettiin investoinneista johtuen aikaisempaa enemmän eli 21700 euroa ja toisaalta niitä lyhennettiin 13300 euroa. Velkojen nettolisäys oli keskimäärin 8400 euroa tilaa kohti. Investointiavustuksia saatiin 2900 euroa eli saman verran kuin edellisenä vuonna.

Kassan ylijäämäksi vuonna 2008 jäi 17800 euroa, joka kattaa rahoitusomaisuuden muutoksen ja jäi käytettäväksi yksityiseen kulutukseen. Vuosina 2000 - 2008 kassan ylijäämä on ollut keskimäärin $15 \%$ rahatuloista.

Kassamenojen kasvu on viime vuosina ollut hieman tulojen kasvua nopeampaa, mutta tulorahoitus ei ole kuitenkaan merkittävästi heikentynyt. Tulorahoituksella on pystytty maksamaan toiminnan menot, rahoitusmenot ja verot ja myös investointeihin on jäänyt rahaa. Positiivinen investointijäämä osoittaa, että investoinnit on voitu keskimäärin rahoittaa tulorahoituksella. Isompia investointeja sillä ei kuitenkaan pystytä rahoittamaan, vaan rahoitukseen käytetään lainoja ja avustuksia. Investointitukien määrä oli vuosina 2007 - 2008 keskimäärin 2900 euroa ja lainojen nettolisäys 8400 euroa tilaa kohti.

\section{Lainojen hoitokate ja vieraan pääoman takaisinmaksuaika}

Tulorahoituksen riittävyyttä voidaan arvioida suhteessa vieraan pääoman hoitomenoihin tai suhteessa investointeihin. Lainojen hoitokate mittaa tulorahoituksen riittävyyttä vieraasta pääomasta aiheutuviin maksuihin. Lainojen hoitokate saadaan jakamalla rahoitusjäämän ja korkomenojen summa lainojen hoitomaksuilla eli lyhennysten ja korkojen summalla. Vieraan pääoman takaisinmaksuaika mittaa velkojen takaisinmaksukykyä ja se lasketaan jakamalla sijoitettu (korollinen) vieras pääoman rahoitusjäämällä.

Molemmat tunnusluvut voidaan laskea eri olettamuksilla yrittäjän voitonjako-osuudesta tulorahavirrasta. Jos koko rahoitusjäämä olisi käytettävissä velkojen hoitokuluihin, olisi lainojen hoitokate vuonna 2008 keskimäärin 2,3 ja velkojen takaisinmaksuaika keskimäärin 2,7 vuotta. Kun yrittäjän osuutena tulorahoituksesta käytetään työlle saatua korvausta eli ns. työn tuottoa, on lainojen hoitokate keskimäärin 1,5 ja velkojen takaisinmaksuaika 4,4 vuotta. Jos yrittäjän osuutena rahoitusjäämästä vähennetään maataloudesta saatu yrittäjätulo, saisi lainojen hoitokate vuonna 2008 arvon 1,2 ja takaisinmaksuaika arvon 5,8 vuotta.

Tässä käytetyillä laskentaperusteilla maksuvalmiutta voidaan pitää yleisten ohjelukujen mukaan tyydyttävänä eli liiketoiminnan kassavirta riittää lainojen hoitokuluihin ja takaisinmaksuajat ovat kohtuullisia. Tunnuslukujen arvot riippuvat kuitenkin varsin paljon siitä, minkä mukaan yksityisotto vähennetään rahoitusjäämästä. Rahoitusjäämää ei voida lyhyelläkään aikavälillä kokonaan käyttää 
velkojen hoitomenoihin, vaan siitä on katettava muutakin rahan käyttöä. Maataloutta voidaan tarvittaessa myös rahoittaa esim. metsä- tai palkkatuloilla.

\section{Maksuvalmius hallinnassa}

Lainojen hoitokatteella mitattu velkojen hoitokyky oli vuonna 2008 heikoin muilla kotieläintiloilla ja sikatiloilla ja paras lypsykarjatiloilla. Velkojen takaisinmaksuaika oli pisin muilla nautakarjatiloilla ja puutarhayrityksissä. Muilla nautakarjatiloilla suuri velkaisuus ja puutarhayrityksissä puolestaan pieni rahoitusjäämä pidensivät takaisinmaksuaikoja. Tunnuslukujen valossa viljatilojen maksuvalmius pysyi kohtuullisena vielä vuonna 2008 vaikka kannattavuus ja yrittäjätulo putosivat rajusti edellisvuodesta. Viljatilojen velkaisuus on myös pysynyt viime vuodet varsin kohtuullisena.

Sikatilojen maksuvalmius heikkeni selvästi vuonna 2008 kannattavuuden pudotessa. Rahamenot ovat kasvaneet tuloja nopeammin voimakkaasti, mikä on heikentänyt rahoitusjäämää vuodesta 2005 lähtien. Toimintajäämä-\% on pudonnut vuosikymmenen alun $37 \%$ :sta $27 \%$ :iin, mikä on selvästi kiristänyt maksuvalmiutta. Investointeja on tehty viime vuosina varsin vähän ja rahoitusjäämää on käytetty velkojen maksuun, mikä on keventänyt velkaisuutta. Lypsykarjatilojen maksuvalmius on pysynyt vähintäänkin tyydyttävänä. Rahoitusjäämä on kasvanut 2000-luvulla rahatulojen vauhdissa ja velkaisuus on pysynyt kohtuullisena. Kahdessa suurimmassa kokoluokassa velkaisuus (velka-\%) ylittää $100 \%$, mutta nykyisen tulorahoituksen ja lainojen hoitokulujen tasolla velkojen hoitokykyä voidaan pitää tyydyttävänä ja maksuvalmius on pysynyt hallinnassa. 